\title{
Human impact on avian diversity in rural Mediterranean areas
}

\author{
Sofia G. Plexida and Athanassios I. Sfougaris* \\ Laboratory of Ecosystem and Biodiversity Management, Department of Agriculture, Crop \\ Production and Rural Environment, University of Thessaly, N. Ionia, Volos, Greece
}

(Received 1 November 2012; accepted 17 April 2013; first published online 6 February 2014)

\begin{abstract}
Human activities influence the biodiversity of Mediterranean ecosystems and are involved in the transformation of natural habitats into farmland. We surveyed birds using the point count method on 288 plots at a 50-m radius in three altitudinal landscapes with different rural character in spring and autumn. The results showed that bird species richness in the study area was high (74 species). High total species richness was found in the upland rural landscape characterized by mixed land use and high landscape diversity. The applied richness of total, resident and Sylviidae species illustrated a definite preference for villages with a low human population during the breeding season. Positive and significant correlations were found between rural settlements and Fringillidae, Sylviidae and total bird richness at both periods in the three landscapes. Finally, a clear dependence on the land use/land cover type was shown for the five recorded priority species.
\end{abstract}

Keywords: landscape structure; bird diversity; land uses; FRAGSTATS; central Greece

\section{Introduction}

Human activities are the main forces shaping land use changes (Blondel 2006; Serra et al. 2008). In particular, areas of the Mediterranean basin have been profoundly transformed by human activity over millennia (Geri et al. 2010). Human determinants influence Mediterranean ecosystems along a gradient in which moderate disturbances enhance biological and landscape diversity, while more intense or prolonged disturbances cause them to shift across ecological thresholds towards increasingly degraded and exploited systems (Blondel and Aronson 1999; Brotons and Reunanen 2005). Traditional farming activities have favoured habitat diversity in Mediterranean holmoak ecosystems, increasing the amount of open areas with no shrubs or trees (Verdú et al. 2000). The relationships between landscape patterns and the interaction of natural and human factors that have influenced and continue to impact the landscape may provide a basis for linking those spatial patterns with biodiversity distribution (Saura and Carballal 2004).

In rural landscapes, habitat heterogeneity from the spatial scale of fields, caused by increasing the number of crops grown per farm, to whole landscapes, is likely to have a broad positive effect on the number of bird species, because more species will be able to find suitable alternative habitats (Benton et al. 2003). Landscape diversity

*Corresponding author. Email: asfoug@agr.uth.gr 
is often measured by the widely used diversity indices Shannon's, Simpson's and Modified Simpson's (McGarigal and Marks 1995). Patch Density (PD) is a limited, but fundamental, aspect of landscape structure providing indications concerning the fragmentation degree of the different land cover types on a whole landscape. Percentage of landscape (PLAND) is the percentage of the landscape comprising a particular patch type. Strong correlations have been demonstrated between bird species and landscape diversity, as birds are often used as biodiversity indicators (Garson et al. 2002).

Birds are frequently used as indicator variables in ecological monitoring and assessment because they constitute a well-defined taxon that has been widely surveyed and are relatively easy to census (Lin et al. 2008). However, the measurement of biodiversity has been surrounded by considerable debate (Pielou 1975; Colwell and Coddington 1994; Gaston 1996; Petchey and Gaston 2002). Nonetheless, there is an urgent need to develop cost-effective methods for biodiversity assessment, avoiding time-consuming approaches. In this context, it is recognized that it may not be possible to measure the target directly and it may be necessary to seek indirect or surrogate measures, which are called biodiversity indicators (Lindenmayer et al. 2002). Species richness is the most frequently used measure in biodiversity studies because it is one of the structural components of diversity (Gaston 1996). Historically, species diversity has been measured by a bewildering range of diversity indices that often consists of two components: the number of species and the relative evenness of their abundances (Magurran 2004). The factor that most explains variation in landscape structure is the distance from the point or area where human settlements start (Antrop 2000; Turner et al. 2001). There are significant differences regarding the distances at which birds of the same species respond to disturbance, depending on disturbance type. These distances are significantly greater during the breeding season (Rutz et al. 2006; Ruddock and Whitfield 2007).

Although many studies have dealt with bird diversity in Mediterranean ecosystems (Farina 1997; Santos et al. 2002; Moreira et al. 2005; Katsimanis et al. 2006; Fonderflick et al. 2010), little attention has been paid to investigating the relationships between rural settlements and avifauna on natural and man-made habitats along an altitudinal gradient (Gao et al. 2009). Previous pioneer studies (Meliadis et al. 1998; Bourdakis 2003) have already recognized the study area as rich in terms of ornithological diversity. In this paper, we investigated how: (1) alpha diversity of avifauna changes relative to human population density of villages in three landscapes with different rural character, (2) bird species richness varies relative to landscape context and diversity, and whether any bird species serve as an indicator of landscape diversity, and (3) bird species richness is affected by rural settlements.

\section{Material and methods}

\section{Study area and landscape classification}

The study was carried out in the Prefecture of Trikala, central Greece (Figure 1). The study area has an extent of $605 \mathrm{~km}^{2}$ and is located at an altitude from 110 to $1300 \mathrm{~m}$. It is part of the NATURA 2000 network of protected areas in Europe (Dafis et al. 1996) due to its importance for the conservation of 163 bird species (Meliadis and Kassioumis 2001). The climate is sub-Mediterranean throughout the majority of the territory with relatively cold winters and warm dry summers, with mean annual air 

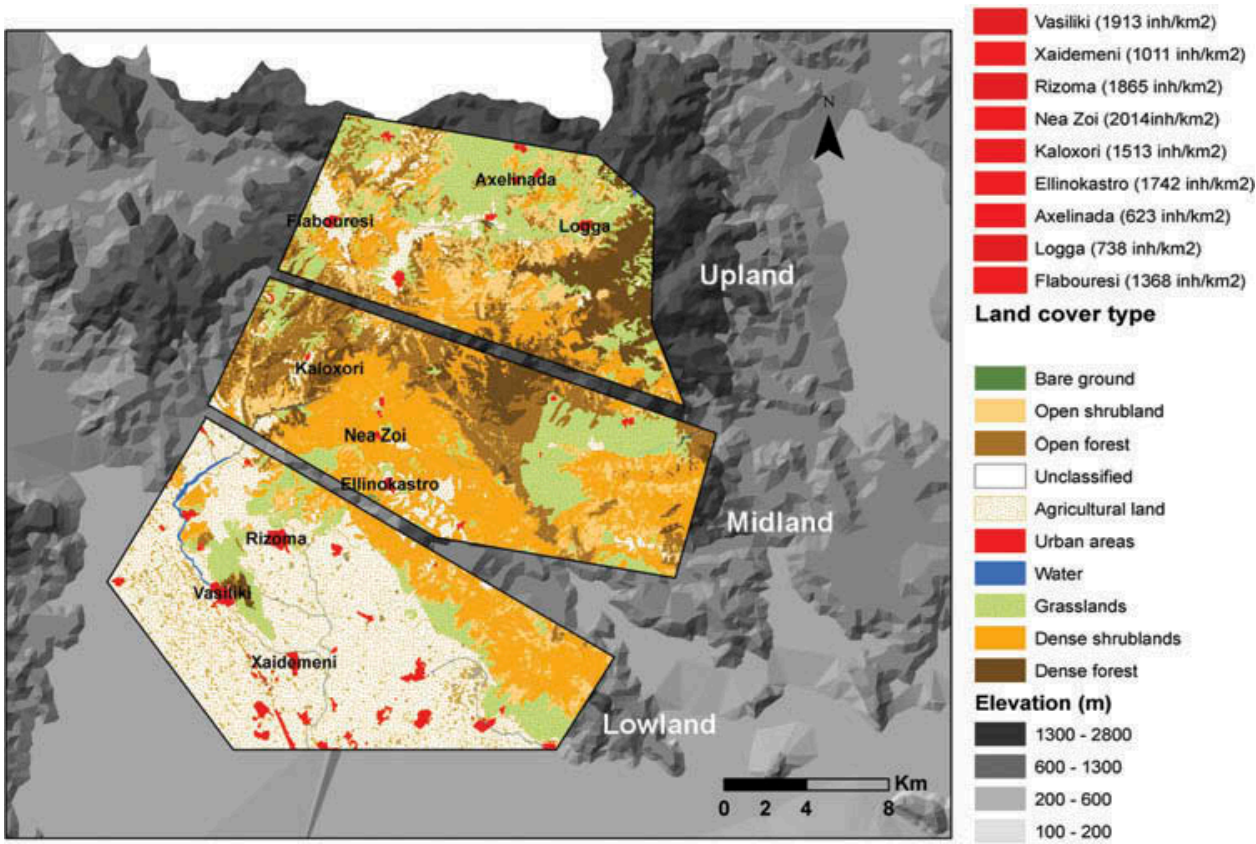

Figure 1. The three landscapes with the selected villages of each landscape of the study area.

temperature $16.8^{\circ} \mathrm{C}$, mean annual air humidity $65.9 \%$ and mean annual precipitation $750 \mathrm{~mm}$ (Hellenic Meteorological Service 2009).

The study area was divided into three landscapes with different rural character based on altitude (Figure 1). The first landscape (lowland) covers an area of approximately $249 \mathrm{~km}^{2}$. Within this area the altitude ranges from 100 to $150 \mathrm{~m}$ and is dominated by intensively used agricultural land. Most of the area (163 ha) is covered by productive monocultures with only a few fields ( 22 ha) still in use for cattle grazing. In some hilly sites, fruit trees are present. The second landscape (midland) is a semi-mountainous area covering a total area of $193 \mathrm{~km}^{2}$ and with an altitudinal range between 200 and $750 \mathrm{~m}$. It is dominated by shrubs such as Pyrus amygdaloformis, Quercus coccifera, Carpinus orientalis and Cotinus coggygria. Shrublands are the main habitat of this landscape ( $95 \mathrm{ha}$ ), revealing how farm activities have been abandoned here, and only a few fields (11 ha) are used in agriculture. Some of these areas also include bedrock and dispersed trees. The third landscape (upland) is mountainous with altitudes ranging from 780 to $1300 \mathrm{~m}$ and has an area of $163 \mathrm{~km}^{2}$. It is dominated by forest vegetation (45 ha) composed of Quercus pubescens stands mixed with Quercus ithaburensis var. cerris and Quercus frainetto, whereas Fagus sylvatica dominates the highest elevations. Its landscape matrix is rather mixed, because agriculture and raising livestock are still the main activities in this rural landscape.

Three villages with different population densities (inhabitants per $\mathrm{km}^{2}$ ) were selected in the three different rural landscapes (lowland, midland, upland) of the study area (Figure 1). Based on subsets of ASTER satellite images, acquired in July 2008 with a spatial resolution of $15 \mathrm{~m}$, a detailed land cover map was obtained. This was produced by performing a supervised classification using the software ENVI 
(Environment for Visualizing Images 4.7, ITT Visual Information Solutions) and applying a maximum likelihood algorithm (Richards 1994). The resulting land cover map was merged into the 10 different existing habitats: dense forest (canopy density of $70 \%$ and above), open forest (canopy density $<70 \%$ ), dense shrublands, open shrublands, grasslands, agricultural land, urban areas, bare land, water and unclassified (Ghossoub 2003).

\section{Sampling}

\section{Bird census}

Bird surveys were conducted using the point count method (Bibby et al. 1992) during the breeding season, from early April to mid June, when birds are easily detectable due to territorial displays and nesting activities, and the autumn of 2009. Bird surveys on the selected circular plots were conducted after systematic sampling. The first observation point was located at the centre of each village, and the next sampling point was $250 \mathrm{~m}$ further away to avoid double counting of a bird species (Bibby et al. 1992) in the four directions of the horizon. A total of 288 point counts was accomplished, 32 sampling points per village. Counts were made with binoculars Nikon 7218 Action, $10 \times 50 \mathrm{~mm}$, by two observers simultaneously.

All individuals of the bird species seen or heard within a 50-m radius of each point were counted. Birds that were flushed when approaching the point and observed within the radius were also included. Each count lasted for $10 \mathrm{~min}$ and took place during the period of maximum bird activity, from dawn to 4 hours after sunrise (Blondel et al. 1970). No bird counts were made on mornings with strong wind or rain (Cody 1985).

The bird species were classified in groups according to the two following criteria: (a) migratory status: resident or migratory; and (b) family: since species belonging to the same family may share characteristics related to behaviour or nesting ecology that may influence the way they are affected by the human impact. For statistical reasons only families with more than two species detected in the area were included in the analyses. Raptors were excluded from the statistical analyses as the point count method is not an appropriate method for recording them.

\section{Richness variables}

The measurement of alpha diversity was based on the mean bird species richness and two diversity indices recorded at each sampling point. Alpha diversity, that measures inventory diversity (e.g. number of species) (Magurran 2004), was described by: (1) Shannon's diversity index $\left(H^{\prime}\right)$ (Shannon and Weaver 1949) despite its sensitivity to sample size and the presence of rare species, and (2) Margalef $\left(D_{M g}\right)$ index. Both diversity indices $H^{\prime}$ and $D_{M g}$ are intuitive meaningful indices and can play a useful role in investigations of biological diversity, despite being strongly influenced by sampling effort (Magurran 2004).

\section{Vegetation descriptors}

Measurements of environmental variables were taken within the same circular plots of $50-\mathrm{m}$ radius where the birds were counted. Vegetation variables measured were: 
cover $(\%)$ of the herbaceous layer, cover $(\%)$ of the shrubs, cover $(\%)$ of the trees, shrub species richness, tree species richness and the heights of shrubs and trees. We also noted the general habitat category of the sampling areas referred to as: (1) agricultural, (2) abandoned fields, (3) rangeland, meaning either grassland or shrubland (Papanastasis and Noitsakis 1992), (4) open forest, and (5) dense forest. To avoid observer-related biases in vegetation sampling (Prodon and Lebreton 1981), all vegetation parameter estimations were conducted by the same observer to control for inter-observer variability (Morrison et al. 1992).

Human impact on the landscapes was examined by recording land uses (e.g. agriculture) as well as by taking into account the distance from rural settlements around the selected villages. Settlements were distinguished as hosting animal husbandry (rural settlements) or abandoned or farming buildings used as a water source (other settlements). The geographical coordinates were recorded by GPS and inserted into the software ArcGIS 9.3 Info (ESRI) and then the distance between landscape sampling points and settlements was measured using the ArcGIS Measure Tool. Additional examined variables were the human population density of each village, the distance from the village centre, altitude and horizon direction of each sampling point.

\section{Data analysis}

Bird data were evaluated for normality and homogeneity of variances with the Kolmogorov-Smirnov test and $\mathrm{F}$ test, respectively. When necessary, square root and $[\log (x+1)]$ transformations were used to normalize data. For analysing the data and calculating diversity indices, specific databases of comma-separated value (CSV) files ( ${ }^{*}$.csv) were made using the program Species Diversity and Richness ver. 4.0. We compared alpha diversity of bird species: (a) between the breeding and non-breeding season, (b) among the three rural landscapes and (c) between each village with different human population density by using one-way analysis of variance, followed by the post hoc Tukey test, using PASW for Windows, version 19.0.0 (SPSS, Inc., Chicago, IL, USA; www.spss.com). Regarding diversity indices, statistical comparisons between the lowland, midland and upland landscape were made by the randomization test of Solow (1993) with 10,000 random iterations. Landscape analysis was performed by calculating specific landscape metrics such as Percentage of Landscape (PLAND), Patch Density (PD) and Shannon's Diversity Index (SHDI). Landscape metrics were calculated for a circular sample region of 300 -m radius $(\sim 14$ ha) within 36 (one bird sampling point with high richness $\times 4$ horizon directions $\times 9$ villages) selected landscape sampling points, characterized by high bird richness during the breeding period where migrant and resident species were recorded. The software FRAGSTATS 3.3 was applied for metrics calculation (McGarigal and Marks 1995). Based on the index PLAND, each selected circular area of 300-m radius was characterized by the dominant land cover type. For example, the circular landscape sampling point was characterized as an agricultural area (AGR), if it consisted of $>70 \%$ cultivations; GRAS, if the cover of shrubs or grasses was $>70 \%$ and MIXED, when it comprised different land cover types. Shannon's Diversity Index is a measure of diversity in community ecology, and was applied to measure the diversity of land cover types in the different landscapes. PD and SHDI were chosen because of their widespread use in landscape analyses and well-documented effectiveness in quantifying spatial patterns 
(Farina 2006; Torras et al. 2009; Peng et al. 2010). Comparison of bird species richness and landscape structure, described by PD and SHDI, among the three landscapes was made using one-way analysis of variance, followed by the Tukey post hoc test.

Interrelationships between bird species richness and landscape diversity were also evaluated using Ward's clustering method for hierarchically grouping different land uses (Krebs 1999). The degree of landscape specialization based on main land use was assessed using the indicator value procedure (IndVal) (Dufrêne and Legendre 1997). IndVal is a percentage that takes its maximum value when the species is present exclusively in all sites of a single cluster. All calculations were carried out using IndVal software (Dufrêne 1999). General linear model for univariate analysis of variance was applied to relate bird species richness to the explanatory variables. In addition, the effect of explanatory variables on the breeding bird density of recorded priority birds was examined. The model fit was made by visual inspection of the residuals. For the statistical analyses the statistical package PASW for Windows version 19.0.0 was used (SPSS, Inc.; www.spss.com).

\section{Results}

\section{Species community structure and composition}

Totals of 55 and 51 bird species were recorded at 288 sampling sites of the whole study area during the breeding season and the non-breeding season of 2009, respectively (Appendix A1). Ten raptor species (Accipiter brevipes, Accipiter gentilis, Accipiter nisus, Buteo buteo, Buteo rufinus, Circaetus gallicus, Falco tinnunculus, Hieraaetus pennatus, Milvus migrans, Pernis apivorus) were excluded from the analyses. The species recorded belong to eight orders and 27 families, with Fringilla coelebs being the most frequently recorded species in both seasons in the whole study area (Appendix A1). Twenty-one species are included in the Annexes of the Birds Directive (2009/147/EC), and six of them (Caprimulgus europaeus, Dendrocopos medius, Dendrocopos syriacus, Lanius collurio, Lanius minor, Lullula arborea) are in Annex I.

\section{Alpha diversity and human settlements}

Mean species richness with standard deviations of the total bird species and all subgroups were calculated for the breeding and non-breeding seasons (Table 1). During the non-breeding season, there were significant differences between bird richness values and villages only for the families Paridae $(F=3.126, p<0.002)$, Picidae $(F=3.097, p<0.002)$ and Turdidae $(F=3.534, p<0.001)$. In contrast, during the breeding season the mean species richness of all groups differed significantly among villages with different human population density to the study area (total bird richness, $F=5.200, p<0.0001$; resident birds, $F=6.968, p<0.0001$; migratory birds, $F=11.103, p<0.0001$; Alaudidae family, $F=5.436, p<0.0001$; Corvidae family, $F=3.438, p<0.001$; Emberizidae family, $F=4.267, p<0.0001$; Fringillidae family, $F=5.335, p<0.0001$; Laniidae family, $F=3.761, p<0.0001$; Muscicapidae family, $F=3.676, p<0.0001$; Paridae family, $F=11.385, p<0.0001$; Picidae family, $F=4.980, p<0.0001$; Ploceidae family, $F=4.055, p<0.0001$; Sylviidae family, $F=13.861, p<0.0001$; Turdidae family, $F=6.059, p<0.0001)$. Some bird groups of the spring community in the lowland landscape (migrant, Emberizidae, Laniidae and 


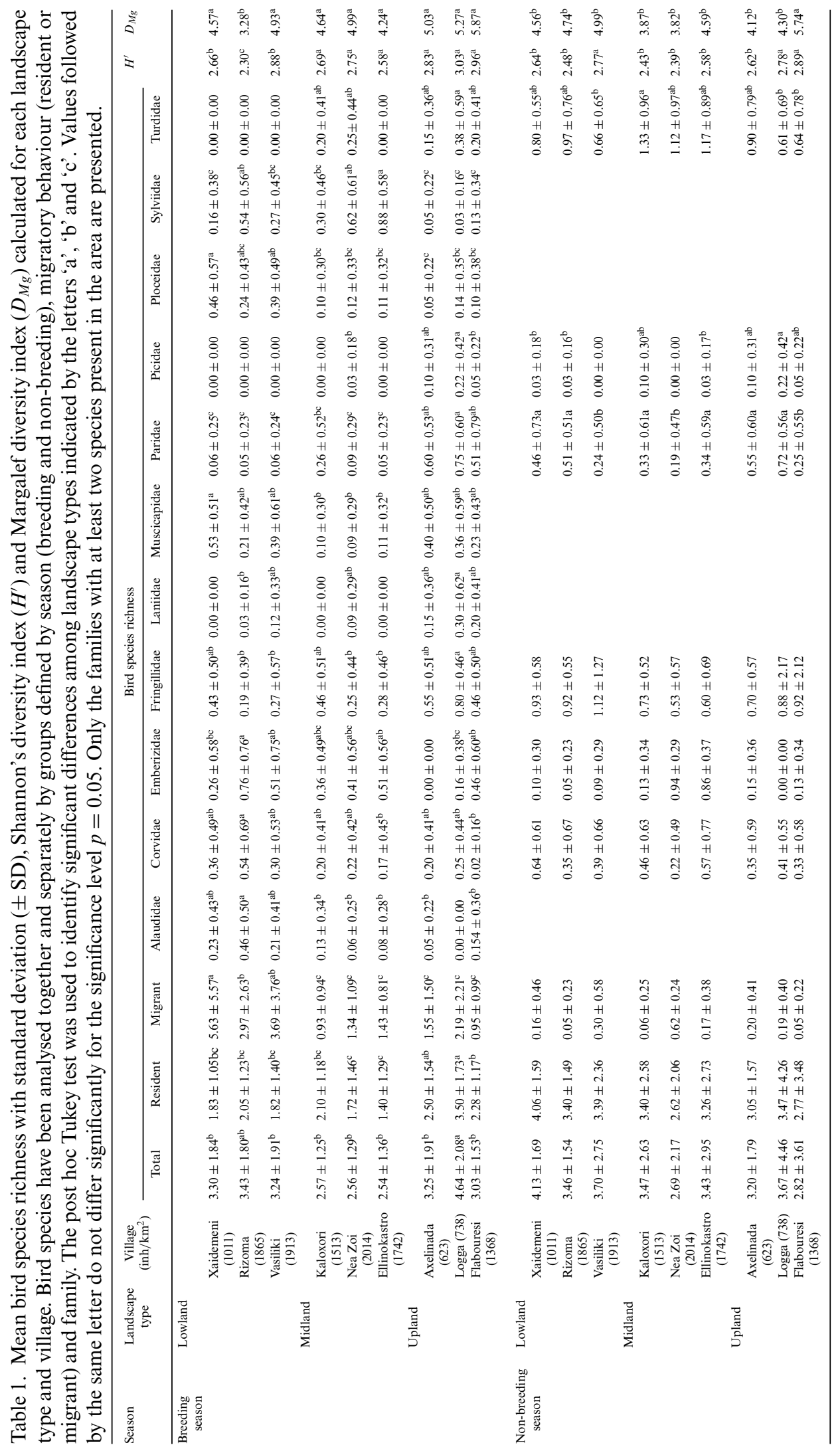


Sylviidae families) differed significantly in mean species richness and diversity indices. Significant differences in bird richness were recorded at the main sampling points, Rizoma and Xaidemeni, which are characterized by low human population density. Migrant species were richer at Xaidemeni, whereas there were more Emberizidae and Sylviidae species in Rizoma than in other areas. In the midland landscape, only Sylviidae species had high mean richness at the villages of Nea Zoi and Ellinokastro. Mean species richness of the total bird species, resident species and Fringillidae species was high at the village of Logga in the upland landscape.

Alpha diversity indices $\left(H^{\prime}\right.$ and $\left.D_{M g}\right)$ varied significantly among the three landscapes based on the randomization Solow test (Table 1). Midland and upland landscapes were more diverse than the lowland one. The highest Shannon's diversity index $\left(H^{\prime}\right)$ values and Margalef's diversity index $\left(D_{M g}\right)$ values were recorded in the uplands. Low values of $H^{\prime}$ were recorded in Rizoma, as well as $D_{M g}$ index values. Values of both alpha diversity indices followed the same sequence in each landscape.

\section{Indicator bird species for landscape diversity}

The whole study area is influenced by human activities and different land cover types were mapped. Based on the landscape metric PLAND, lowlands were covered mostly by arable crops whereas midlands were covered by rangelands. The uplands were characterized by a rather mixed farmland-forest mosaic. Significant differences in landscape diversity (SHDI) were detected at the 36 selected landscape sampling sites with high bird species richness (SHDI, $F=3.876, p<0.030$ ), with the lowest SHDI exhibited in the lowland landscape. A post hoc Tukey test showed that the midland landscape was significantly more diverse than the lowland, but did not differ significantly in comparison to the upland.

The IndVal method was used to define species indicative of specific landscape diversity. Species with indicator values of at least $80.00 \%$ are usually characterized as specialists to particular landscape diversity. Two species were identified as landscape diversity specialists in this study (Figure 2). Fringilla coelebs (IndVal $=80.00 \%$ ) and Sitta europaea $(\mathrm{IndVal}=83.55 \%$ ) were indicators of highly diverse landscapes, whereas Delichon urbica, Hippolais pallida, Luscinia megarhynchos, Merops apiaster, Passer domesticus and Pica pica were considered indicators of homogeneous landscapes.

\section{Species-landscape relationship models}

During the breeding season, the best models explained a percentage of $10.4 \%, 13.9 \%$ and $16.8 \%$ of the total bird species richness variance in lowland, midland and upland landscapes, respectively (Table 2). In the lowland landscape, the model proved that areas at low altitude $(t=-2.266, p<0.026)$, close to rural settlements $(t=-2.526$, $p<0.013)$ with high tree species richness $(t=2.367, p<0.020)$ positively affected the total bird richness. Shrub species richness and cover have a positive effect on Emberizidae richness $\left(F=8.143, p<0.005\right.$, adjusted $R^{2}=0.070$, df $\left.=95\right)$ and Laniidae richness $\left(F=62.814, p<0.0001\right.$, adjusted $\left.R^{2}=0.394, \mathrm{df}=95\right)$, respectively. The model shows Sylviidae species have a definite preference for rural settlements $(t=-2.156, p<0.034)$ and avoid trees $(t=-2.277, p<0.025)$. In the autumn, the models for the total bird and Emberizidae species richness were explained best by 


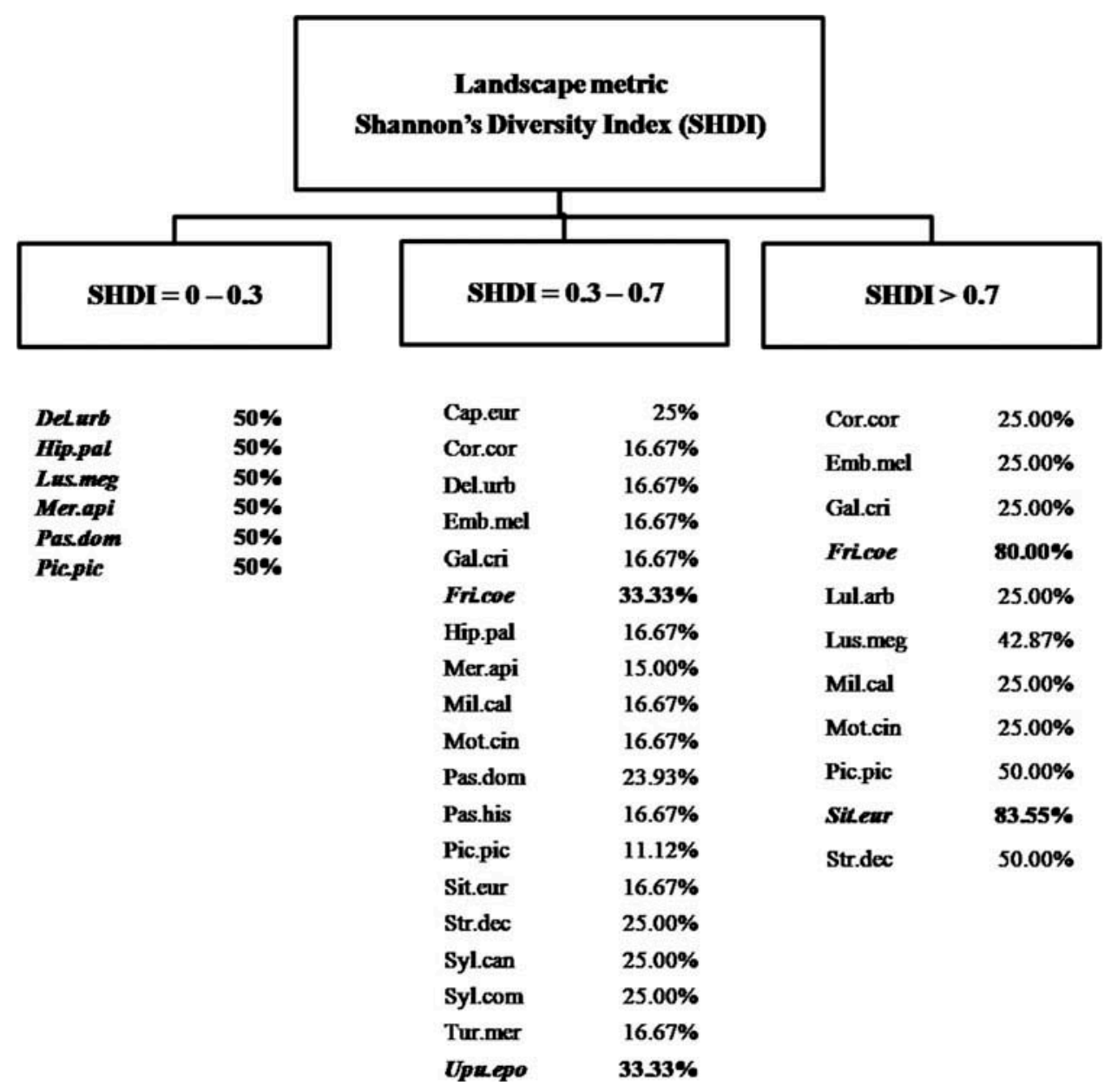

Figure 2. Indicator species with statistically significant $(p<0.01)$ values of the IndVal index. The maximum index value for each species is denoted by italics.

habitat type $\left(F=5.364, p<0.002\right.$, adjusted $R^{2}=0.122$, df $\left.=95\right)$ and shrub richness $\left(F=9.399, p<0.003\right.$, adjusted $R^{2}=0.081$, df $\left.=95\right)$, respectively. No Laniidae species were recorded, whereas only Phylloscopus collybita was recorded in the family Sylviidae.

In the midland area during the breeding season, the best model for total bird richness showed that areas with a high number of shrub $(t=2.491, p<0.015)$ and tree $(t=2.944, p<0.004)$ species and distant from other settlements $(t=2.061$, $p<0.042)$ were preferred. The model for Sylviidae species richness showed some strong associations: there was a definite preference for villages with low human population density $(t=-4.369, p<0.0001)$. In contrast, in the autumn, the best model showed for total bird richness that proximity to rural settlements $(t=-3.711$, $p<0.0001)$ and herbaceous cover $(t=2.007, p<0.048)$ were preferred. No Sylviidae species were recorded. 


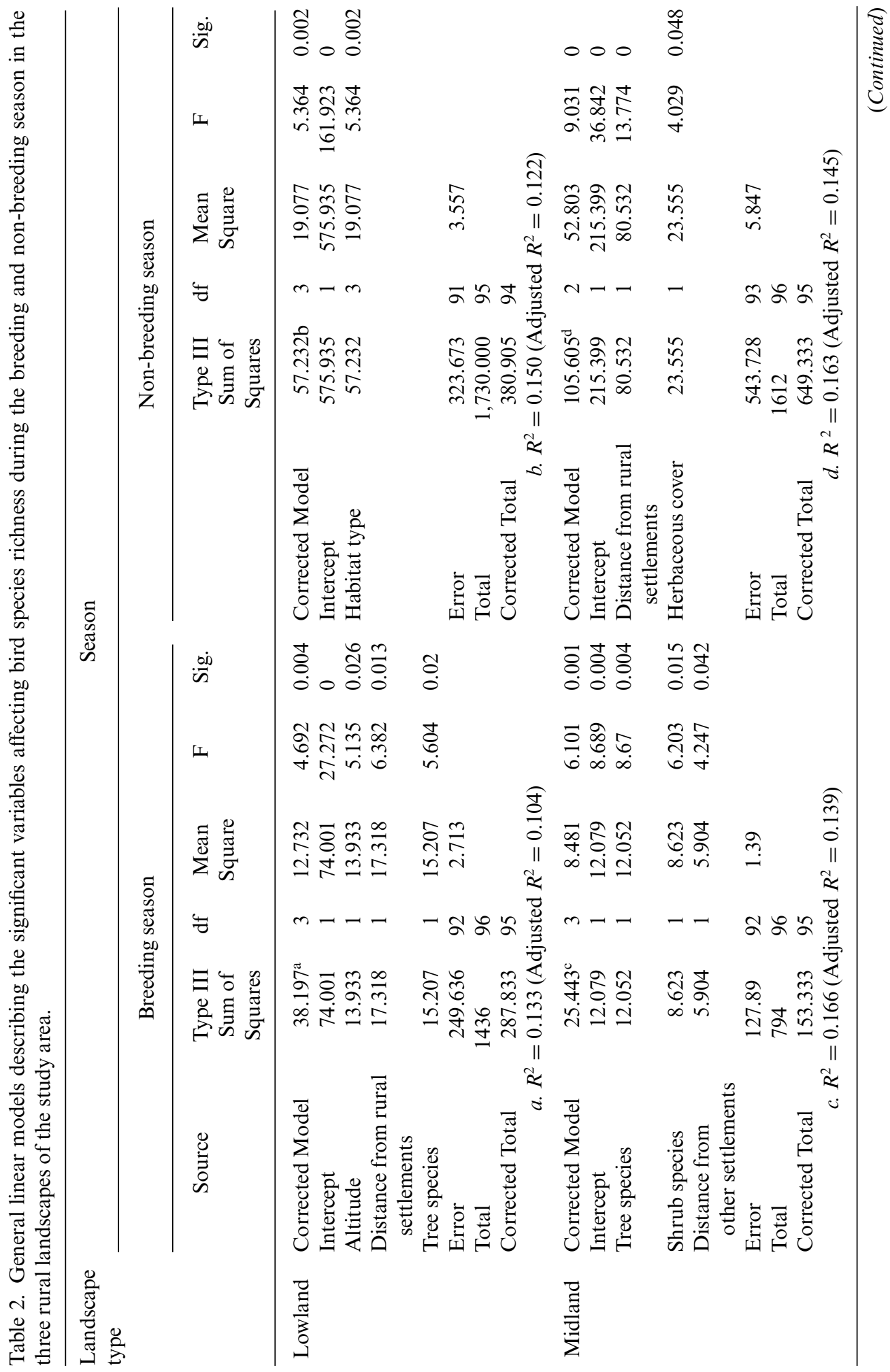


In the upland, the models for the total and resident species richness, during the breeding season, showed that high shrub richness $\left(t_{\text {total }}=3.967, p<0.0001\right.$; $\left.t_{\text {resident }}=2.621, p<0.023\right)$ and low human population density $\left(t_{\text {total }}=-2.104\right.$, $p<0.038$; $t_{\text {resident }}=-2.311, p<0.010$ ) were preferred. However, in the autumn, these two bird groups showed different habitat associations. The model for total bird richness showed that areas close to rural settlements $(t=-3.476, p<0.010)$ and rangelands $(t=3.307, p<0.001)$ were the preferred habitat conditions, whereas resident species preferred areas close to rural settlements $(t=-4.130, p<0.0001)$, but with less tree cover $(t=-2.198, p<0.030)$. Fringillidae species preferred areas with high tree cover during the breeding season $\left(t=3.731, p<0.0001\right.$, adjusted $R^{2}=0.012$, df $\left.=95\right)$. In the autumn, Fringillidae species preferred areas close to villages $(t=-2.354$, $p<0.021)$ and rather herbaceous areas $(t=2.473, p<0.015)$.

Regarding the five recorded priority birds (Dendrocopos medius, Dendrocopos syriacus, Lanius collurio, Lanius minor, Lullula arborea) in the whole study area during the breeding season, the best models for the breeding density of $D$. syriacus were affected by high altitude $\left(F=6.68, p<0.010\right.$, adjusted $\left.R^{2}=0.100, \mathrm{df}=287\right)$ and high tree cover $\left(F=11.38, p<0.001\right.$, adjusted $\left.R^{2}=0.100, \mathrm{df}=287\right)$. The best models for Laniidae species (Lanius collurio and Lanius minor), explained $14 \%$ and $2.6 \%$ of their breeding density variances as due to high altitude and open agropastoral habitats, and high shrub richness, respectively. Furthermore, the breeding density of Lullula arborea was positively affected by high altitude and high cover of herbaceous plants (adjusted $R^{2}=0.036, \mathrm{df}=287$ ). During the non-breeding season, only two priority species were recorded, D. medius and D. syriacus. The best models explained $5.1 \%$ and $0.9 \%$ of their breeding density variances as being due to habitat type and high tree cover for $D$. medius and rangelands for D. syriacus, respectively.

\section{Discussion}

\section{Species response to the landscape's rural character}

Our results have shown that interpretation of landscape context effects on bird richness is a rather complex task. Out of the 74 species, $F$. coelebs was the most frequently occurring bird during both periods examined. This may be because cereals are cultivated in the whole study area, and cereal seeds are its main food (Lack 1986). During the breeding season, apart from Fringilla coelebs - Luscinia megarhynchos, Miliaria calandra, Passer domesticus and Sylvia cantillans were the most frequently observed species.

During the autumn, three species were the most frequently observed: Fringilla coelebs, Erithacus rubecula and Turdus merula. Erithacus rubecula feeds mainly on insects, spiders and small seeds, and it nests on the ground (Cramp, Simmons, and Perrins 1977-1994). Although it is reported in the literature (Díaz et al. 1998; Santos et al. 2002) as a woodland species that needs woody vegetation, shrubs or trees, and that can feed in pastures, in our study its highest frequency was recorded in the agricultural lowland landscape (21.87\%). Possibly, this is because it is a generalist species and colonizes a wide range of habitats. Turdus merula showed highest occurrence in the midland shrubby landscape (18\%), compared with $10.41 \%$ in the upland landscape and only $6.5 \%$ in the lowland landscape. This is easily explained for the breeding season because it builds nests in trees or shrubs. In accordance with our results, Díaz et al. 
(1998) and Santos et al. (2002) classified it as a woodland species breeding in bushes or trees, whereas Katsimanis et al. (2006) showed that the species is stenotypic in the Mediterranean shrublands of Crete.

Based on the character of each rural landscape, a richness of migrant species and species of Alaudidae, Corvidae, Emberizidae, Muscicapidae and Ploceidae families was higher than in the other landscapes. Moreover, migrant bird species breeding in Europe have been shown to favour open habitats, a pattern that is interpreted as an evolutionary conservation of niche properties of long-migrant species that originated in tropical Africa (Böhning-Gaese and Oberrath 2003). Although it is known that intensification of modern agriculture, concomitant abandonment of traditional farming, and elimination of non-crop habitats, such as semi-natural grasslands, has drastically altered farmland mosaics (Söderström et al. 2001; Petit 2009), a satisfactory number of bird species was recorded in lowlands. As expected, some species were not recorded in this homogeneous agricultural landscape, as it is widely recognized that a sharp decline in the abundance and distribution of grassland birds has been observed in the agricultural landscapes of Europe (Donald et al. 2001, 2006). On the contrary, human activities in the study area, such as agriculture and cattle breeding, created suitable open habitats for the emberizids, as found by Cestari and Pacheco (2010). The interpretation of the model for Emberizidae is somewhat complicated and caused by the contradictory information presented in the literature. Stoate et al. (2000) have associated emberizids with arable land because they eat mostly seeds and insects (Dunning 2001; Dickinson 2003), whereas in our study they showed a preference for shrubby areas with high shrub richness. This could be the result of the presence of small shrubs in the recorded areas, causing nests to be built on the ground or in shrubs $1 \mathrm{~m}$ above the ground.

The lowest total bird richness of both seasons was recorded in the midland landscape. Probably, the increased abundance of the Sylviidae family reflects the dominance of shrubs and abandoned cultivations in the midlands, which supports mostly caterpillars and spiders, in accordance with its cultural ecology. The upland landscape includes different habitat types, variable landscape features (scattered shrubs, trees, forest openings, torrents), and increasing landscape diversity, which positively influenced bird richness, a result that may also arise from components of other ecological functions. The traditional rural landscape in the uplands provided Laniidae species with a large amount of ecotonal habitat, with many sites for nesting. Consequently, mean species richness of the bird groups, resident, Laniidae and Paridae were higher at the villages Axelinada and Logga, both belonging to the upland landscape. This may be because Laniidae and Paridae species spend a lot of time sitting in the tops of trees and shrubs searching for insects, so the mixed farmland-forested landscape in the uplands possibly favours the presence of these bird families. Additionally, the pastoral character of alpine areas could explain the observed high occurrence of Lanius collurio. Finally, several study species were affected by the altitude, in accordance with other studies (Gaston 2000; Maclean et al. 2006).

\section{Landscape diversity}

Our results suggest that landscape diversity was high in grassland or a mosaic of land cover types, whereas arable-land-dominated landscapes demonstrated low diversity. Rural areas characterized by high patch density (PD) and high landscape diversity 
(SHDI), such as the midlands and uplands, proved favourable landscapes for birds. This has been attributed to the fact that a large number of land cover types are able to meet the needs of many different bird species (woodland, farmland, shrubland, urban) and thereafter their spatial separation reduces their competition (Berg 1997; Santos and Tellería 1997). Similarly, other studies from the Mediterranean (Atauri and De Lucio 2001; Moreira et al. 2005) have concluded that few bird species are recorded in homogeneous rural landscapes. More specifically, the response of bird species to landscape attributes has been shown to be both taxon- and scale-dependent, but there is a consistently positive relationship between high landscape heterogeneity and bird species richness and turnover at the landscape scale (Atauri and de Lucio 2001; McInnes et al. 2009). In Greece, Tsiakiris et al. (2009) reported that high diversity of land cover types increases the diversity of common farmland bird species and Schindler et al. (2008) drew the same conclusion for raptors in Dadia National Park. In central Europe, Wrbka et al. $(1999 ; 2008)$ concluded that plant, bird and bryophyte species richness is positively correlated with landscape heterogeneity. Regarding PD, Herrando and Brotons (2002) studied bird species richness in Mediterranean forests and also concluded that the effect of patch density varied depending on the ecology of each bird species. Other ecological studies (Diniz-Filho et al. 2003; Lin et al. 2008) have shown that nearly all macroecological and biodiversity data exhibit strong spatial patterns, which are driven by spatially structured biological processes.

At bird species level, Fringilla coelebs and Sitta europaea were characterized as indicator species of highly diverse landscapes. In our rural landscapes, Sitta europaea was recorded in the uplands, as expected, where there is a suitable extent of wood area and enough openings. Eurasian nuthatches are small resident birds of mature broadleaved woodlands that live in territories of $1-3$ ha and remain in pairs throughout the year for feeding and breeding (Cramp and Perrins 1993). Young birds do not disperse further than $3 \mathrm{~km}$ (Matthysen and Schmidt 1987; van Langevelde 2000). Some studies have found that breeding densities are higher in large continuous woods than in small isolated ones (Verboom et al. 1991; Matthysen 1999), whereas another study (González-Varo et al. 2008) has reported positive effects of isolation on the abundance of the Eurasian nuthatch. On the other hand, Delichon urbica and Passer domesticus were indicators of homogeneous areas, as expected, because they like areas that have been modified by humans, including farms and residential areas.

\section{Distance effect from rural settlements}

The novelty of this study is that effects of rural settlements on different bird groups were studied along three landscapes with different rural characters. Most of the recent studies have compared the effects of landscape structure on bird richness in a rural context (Fahrig 2003; Cerezo et al. 2011), but commonly underestimated anthropogenic variables as possible modulators of habitat conditions and landscape structure.

Our results showed positive and significant correlations between rural settlements and total bird richness, Sylviidae and Fringillidae species richness. On the whole, at both examined seasons, significant univariate relationships showed that bird richness increases close to rural settlements, indicating landscapes where the existence of traditional farming activities and animal husbandry are beneficial to birds. This may be because human activities have strongly affected the surrounding landscape of villages in the study area, resulting in a variety of land uses, such as agriculture, 
forestry and livestock grazing. These results can be related to high food availability around the rural settlements, especially for species of Passeriformes. This may be because rural birds tend to eat more waste seed from animal dung and seed from fields. Similarly, Brak et al. (2004) have shown the positive effect on bird and vegetation diversity of extensive livestock production in areas of high natural value in Scotland.

Finally, our data highlight that priority bird species in the study area, belonging to the families Alaudidae, Laniidae and Picidae, were significantly affected by the cover of herbaceous plants, habitat type and cover of shrubs, and cover of trees respectively. Our study indicated that Lullula arborea which is a ground nesting bird associated with extensive agriculture, was in high densities in uplands. Conceptión and Díaz (2011) characterized Lullula arborea as a small open-land bird, which is in accordance with our study where the general linear model indicates a clear preference for herbaceous cover. An explanation for that is based on its behaviour, whereby it runs rather than hops along the ground and rarely perches on shrubs and trees, except occasionally to sing (Dean et al. 1992).

In addition, it is remarkable that rural settlements had no effect on priority bird densities, so long as species were able to find food, shelter and nesting sites. Regarding Lanius species, this may be partly because of their ecology, because preferred breeding habitats must provide adequate cover for its nests (Muller et al. 2005), so areas with scattered trees, shrubs and hedges are needed because they create more supervisory positions for the species leading to successful predation (Brambilla et al. 2007). Sol et al. (2005) have also suggested that migratory Lanius species might be more sensitive to habitat changes than resident species.

\section{Conclusions}

Our findings lead to the novel suggestion that rural settlements have positive effects on bird richness and should be maintained in an environmentally friendly way for the wildlife. Also, this study has shown that low human population density of villages increases the total bird species richness. Probably, the process of the development of villages has entailed the elimination of native vegetation. We have identified that, among the features that are amenable to management, low human population, landscape diversity and the presence of rural settlements are the variables that most influence the total bird species richness. Hence, strategies directed at preserving these parameters in the landscape will contribute substantially to the maintenance of bird diversity. Specifically, there should not be monocultures leading to homogeneous farmscapes, but a variety of different productive crops in lowlands and a maintenance of agriculture in uplands, both leading to a diverse landscape. Based on our findings, we recommend that, whenever possible, native vegetation, shrubs or trees, should be maintained and the traditional farming and livestock activities should be kept and promoted by land stakeholders.

\section{Acknowledgements}

We express our gratitude to Pantelis Konstantinou and Apostolis Christopoulos for their help in bird censuses. 


\section{S.G. Plexida and A.I. Sfougaris}

\section{References}

Antrop M. 2000. Changing patterns in the urbanized countryside of Western Europe. Landsc Ecol. 15:257-270.

Atauri JA, De Lucio JV. 2001. The role of landscape structure in species richness distribution of birds, amphibians, reptiles and lepidopterans in Mediterranean landscapes. Landsc Ecol. 16:147-159.

Benton TG, Vickery JA, Wilson JD. 2003. Farmland biodiversity: is habitat heterogeneity the key?. Trends Ecol Evol. 18:182-188.

Berg A. 1997. Diversity and abundance of birds in relation to forest fragmentation, habitat quality and heterogeneity. Bird Study. 44:355-366.

Bibby CJ, Burgess ND, Hill BA, Mustoe SH. 1992. Bird census techniques. London: Academic Press.

Blondel J. 2006. The 'design' of Mediterranean landscapes: a millennial story of humans and ecological systems during the historic period. Human Ecol. 34:713-729.

Blondel J, Aronson J. 1999. Biology and Wildlife of the Mediterranean Region. New York: Oxford University Press.

Blondel J, Ferry C, Frochot B. 1970. La method des indices ponctuels d'abundance (I.P.A.) ou des relevés d'avifaune par "stations d'écoute". Alauda. 38:55-71.

Böhning-Gaese K, Oberrath R. 2003. Macroecology of habitat choice in long-distance migratory birds. Oecologia. 137:296-303.

Bourdakis S. 2003. Report on the bird monitoring in "Antichasia Ori - Meteora" during 2003. Project LIFE - Nature B4-3200/97/243. Managing Actions of Special Protection Areas (SPAs) in Greece. NAGREF, Agricultural Research Station of Ioannina.

Brak BH, Hilarides L, Elbersen BS, van Wingerden WKRE. 2004. Extensive livestock systems and biodiversity: The case of Islay. Wageningen: Alterra.

Brambilla M, Rubolini D, Guidali F. 2007. Between land abandonment and agricultural intensification: Habitat preferences of Red-backed Shrikes Lanius collurio in low-intensity farming conditions. Bird Study. 54:160-167.

Brotons L, Reunanen P. 2005. The role of landscape patterns and land-use history in the composition of bird assemblages in Mediterranean and boreal forest ecosystems. Rev Catalana d'Ornitol. 21:47-57.

Cerezo A, Conde MC, Poggio SL. 2011. Pasture area and landscape heterogeneity are key determinants of bird diversity in intensively managed farmland. Biodivers Conserv. 20:2649-2667. doi: 10.1007/s10531-011-0096-y

Cestari C, Pacheco JF. 2010. Aves, Emberizidae, Coryphospingus pileatus (Wied, 1821): a new gathered bird species to São Paulo state and evidences of southern geographic expansion in Brazil. Checklist. 6:501-502.

Cody ML. 1985. Habitat Selection in Birds. San Diego, California: Academic Press. p. 558.

Colwell RK, Coddington JA. 1994. Estimating terrestrial biodiversity through extrapolation. In: Hawksworth, DL, editor. Biodiversity: measurement and estimation. London, UK: The Royal Society; pp. 101-118.

Conceptión ED, Díaz M. 2011. Field, landscape and regional effects of farmland management on specialist open-land birds: Does body size matter?. Agric Ecosyst Environ. 142:303-310.

Cramp S, Perrins CM (eds). 1993. The birds of western Paleartic. vol 7. UK: Oxford University Press, Oxford.

Cramp S, Simmons K, Perrins C. 1977-1994. The birds of the western Palearctic. Volume I-IX. Oxford: Oxford University Press.

Dafis S, Papastergiadou E, Georghiou K, Babalonas D, Th G, Papageorgiou M, Lazaridou E, Tsiaoussi B. 1996. The Greek Habitat Project: NATURA 2000. An Overview. Commission of the European Communities, Goulandris Natural History Museum. 
Dean W, Fry C, Keith S, Lack P. 1992. Family Alaudidae: Larks. In: Keith S, Urban E, Fry C, editors. The birds of Africa. Vol. IV. London: Academic Press; pp. 13-124.

Dickinson E. 2003. The Howard and Moore Complete Checklist of Birds of the World. 3rd edition. London: Christopher Helm.

Diniz-Filho JAF, Bini LM, Hawkins BA. 2003. Spatial autocorrelation and red herrings in geographical ecology. Global Ecol Biogeogr. 12:53-64.

Donald PF, Green RE, Heath MF. 2001. Agricultural intensification and the collapse of Europe's farmland bird populations. Proc R Soc Lond B Biol Sci. 268:25-29.

Donald PF, Sanderson FJ, Burfield IJ, van Bommel FPJ. 2006. Further evidence of continentwide impacts of agricultural intensification on European farmland birds, 1990-2000. Agric Ecosyst Environ. 116:189-196.

Dufrêne M. 1999. IndVal or how to identify indicator species of a sample typology [Internet]. Available from: http://mrw.wallonie.be/dgrne/sibw/outils/indval/home.html

Dufrêne M, Legendre P. 1997. Species assemblages and indicator species: The need for a flexible asymmetrical approach. Ecol Monogr. 67:345-366.

Dunning J. 2001. New World Sparrows. In: Elphick C, Dunning J, Sibley D, editors. The sibly guide to bird life and behavior. New York: Alfred A. Knopf; pp. 516-535.

Díaz M, Carbonell R, Santos T, Tellerrá JL. 1998. Breeding birds communities in pine plantations of the Spanish plateaux: biogegraphy, landscape and vegetation effects. J Appl Ecol. 35:562-574.

Fahrig L. 2003. Effects of habitat fragmentation on biodiversity. Annu Rev Ecol Evol Syst. 34:487-515.

Farina A. 1997. Landscape structure and breeding bird distribution in a sub-Mediterranean agro-ecosystem. Landsc Ecol. 12:365-378.

Farina A. 2006. Principles and methods in landscape ecology. Towards a science of landscape. The Netherlands: Springer.

Fonderflick J, Caplat P, Lovaty F, Thévenot M, Prodon R. 2010. Avifauna trends following changes in a Mediterranean upland pastoral system. Agric Ecosyst Environ. 137:337-347.

Gao JF, Maa KM, Feng ZW, Qi J, Feng Y. 2009. Coupling effects of altitude and human disturbance on landscape and plant diversity in the vicinity of mountain villages of Beijing, China. Acta Ecologica Sinica. 29:56-61.

Garson J, Aggarwal A, Sarkar S. 2002. Birds as surrogates for biodiversity: an analysis of a data set from southern Quebec. J Biosci. 27:347-360.

Gaston KJ. 1996. Species richness: measure and measurement. In: Gaston KJ, editor. Biodiversity: a biology by numbers and difference. Oxford, UK: Blackwell Science; pp. $77-113$.

Gaston KJ. 2000. Global patterns in biodiversity. Nature. 405:220-227.

Geri F, Rocchini D, Chiarucci A. 2010. Landscape metrics and topographical determinants of large-scale forest dynamics in a Mediterranean landscape. Landsc Urban Plan. 95:46-53.

Ghossoub R. 2003. Impact of piospheric points in Mediterranean rangelands. Master Thesis. Chania, Crete: Mediterranean Agronomic Institute.

González-Varo JP, López-Bao JV, Guitián J. 2008. Presence and abundance of the Eurasian nuthatch Sitta europaea in relation to the size, isolation and the intensity of management of chestnut woodlands in the NW Iberian Peninsula. Landsc Ecol. 23:79-89.

Hellenic Meteorological Service. 2009. Available from: http://www.hnms.gr/hnms/english/ index_html

Herrando S, Brotons L. 2002. Forest bird diversity in Mediterranean areas affected by wildfires: a multi-scale approach. Ecography. 25:161-172.

Katsimanis N, Dretakis M, Akriotis T, Mylonas M. 2006. Breeding bird assemblages of eastern Mediterranean shrublands: composition, organisation and patterns of diversity. J Ornithol. 147:419-427.

Krebs CJ. 1999. Ecological Methodology. 2nd edition. Menlo Park: Addison-Welsey. 
Lack P. 1986. The Atlas of wintering birds in Britain and Ireland. London: T \& A D Poyser Ltd. Lin YP, Yeh MS, Deng DP, Wang YC. 2008. Geostatistical approaches and optimal additional sampling schemes for spatial patterns and future sampling of bird diversity. Global Ecol Biogeogr. 17:175-188.

Lindenmayer DB, Cunningham RB, Donnelly CF, Lesslie R. 2002. On the use of landscape surrogates as ecological indicators in fragmented forests. Forest Ecol Manage. 159:203-216.

Maclean IMB, Hassall M, Boar RR, Lake IR. 2006. Effects of disturbance and habitat loss on papyrus-dwelling passerines. Biol Conserv. 131:349-358.

Magurran AE. 2004. Measuring biological diversity. USA: Blackwell Publishing.

Matthysen E. 1999. Nuthatches (Sitta europaea: Aves) in forest fragments: demography of a patchy population. Oecologia. 119:501-509.

Matthysen E, Schmidt K-H. 1987. Natal dispersal in the nuthatch. Ornis Scand. 18:313-316.

McGarigal K, Marks BJ. 1995. FRAGSTATS: Spatial Pattern Analysis Program for Quantifying Landscape Structure. General Technical Report PNW-GTR-351. U.S. Department of Agriculture, Forest Service, Pacific Northwest Research Station, Portland, OR.

McInnes L, Purvis A, Orme CDL. 2009. Where do species' geographic ranges stop and why? Landscape impermeability and the afrotropical avifauna. P Roy Soc B. 276:3063-3070.

Meliadis I, Bousbouras D, Hallmann B. 1998. Documentation Report of the Joint Ministerial Decision (JMD) on: Conservation Special Protection Area (bird) "Antichasia OriMeteora”. NAGREF - Greek Ornithological Society - Ministry, p.15.

Meliadis I, Kassioumis K. 2001. The combined use of remote sensing and GIS for the study of a Special Protected Area in Greece. Paper presented at: International Conference Ecosystems and Sustainable Development Proceedings of the third International Conference Ecosystems and Sustainable Development, Alicante, Spain.

Moreira F, Beja P, Morgado R, Reino L, Gordinho L, Delgado A, Borralho R. 2005. Effects of field management and landscape context on grassland wintering birds in Southern Portugal. Agric Ecosyst Environ. 109:59-74.

Morrison ML, Marcot BG, Mannan RW. 1992. Wildlife-Habitat Relationships. Concepts and Applications. Wisconsin: University of Wisconsin press.

Muller M, Pasinelli G, Schiegg K, Spaar R, Jenni L. 2005. Ecological and social effects on reproduction and local recruitment in the red-backed shrike. Oecologia. 143:37-50.

Papanastasis V, Noitsakis V. 1992. Livadiki oikologia. Thessaloniki (in Greek): Giachudi editions.

Peng J, Wang Y, Zhang Y, Wu J, Li W, Li Y. 2010. Evaluating the effectiveness of landscape metrics in quantifying spatial patterns. Ecol Indic. 10:217-223.

Petchey OL, Gaston KJ. 2002. Functional diversity (FD), species richness and community composition. Ecol Lett. 5:402-411.

Petit S. 2009. The dimensions of land use change in rural landscapes: lessons learnt from the GB Countryside Surveys. J Environ Manag. 90:2851-2856.

Pielou EC. 1975. Ecological diversity. New York, New York, USA: Wiley.

Prodon R, Lebreton JD. 1981. Breeding avifauna of a Mediterranean succession: the holm and cork oak series in eastern Pyrenees. I: analyses and modelling of the structure gradient. Oikos. 37:21-38.

Richards JA. 1994. Remote Sensing Digital Image Analysis. Berlin: Springer - Verlag.

Ruddock M, Whitfield DP. 2007. A Review of Disturbance Distances in Selected Bird Species. A report from Natural Research (Projects) Ltd. to Scottish Natural Heritage.

Rutz C, Bijlsma RG, Marquiss M, Kenward RE. 2006. Population limitation in the northern goshawk in Europe: a review with case studies. Stud Avian Biol. 31:158-197.

Santos T, Tellería JL. 1997. Efectos de la fragmentación sobre las aves insectívoras forestales en dos localidades europeas. Ardeola. 44:113-117. 
Santos T, Tellería JL, Carbonell R. 2002. Bird conservation in fragmented Mediterranean forests of Spain: effects of geographical location, habitat and landscape degradation. Biol Conserv. 105:113-125.

Saura S, Carballal P. 2004. Discrimination of native and exotic forest patterns through shape irregularity indices: An analysis in the landscapes of Galicia, Spain. Landsc Ecol. 19:647-662.

Schindler S, Poirazidis K, Wrbka T. 2008. Towards a core set of landscape metrics as a prerequisite for biodiversity assessments: a case study from Dadia NP, Greece. Ecol Indic. 8:131-145.

Serra P, Pons X, Saurì D. 2008. Land-cover and land-use change in a Mediterranean landscape: a spatial analysis of driving forces integrating biophysical and human factors. App Geogr. 28:189-209.

Shannon CE, Weaver W. 1949. The mathematical theory of communication. Chicago: University of Illinois Press.

Söderström B, Svensson B, Vesspy K, Glimskär A. 2001. Plants, insects and birds in seminatural pastures in relation to local habitat and landscape factors. Biodivers Conserv. 10:1839-1863.

Sol D, Lefebrvre L, Rodriguez-Teijeiro JD. 2005. Brain size, innovative propensity and migratory behaviour in temperate Palearctic birds. Proc Biol Sci. 272:1433-1441. doi:10.1098/rspb.2005.3099

Solow AR. 1993. A simple test for change in community structure. J Anim Ecol. 62:191-193.

Stoate C, Borralho R, Araújo M. 2000. Factors affecting corn bunting Miliaria calandra abundance in a Portuguese agricultural landscape. Agric Ecosyst Environ. 77:219-226.

Torras O, Martin-Queller E, Saura S. 2009. Relating landscape structure, environment and management to forest biodiversity indicators in Mediterranean landscapes. Invest Agrar Sist Recur For. 18:322-337.

Tsiakiris R, Stara K, Pantis J, Sgardelis S. 2009. Microhabitat Selection by Three Common Bird Species of Montane Farmlands in Northern Greece. Environ Manag. 44:874-887.

Turner MG, Gardner RH, O'Neill RV. 2001. Landscape Ecology in Theory and Practice: Pattern and Process. New York: Springer.

Van Langevelde F. 2000. Scale of habitat connectivity and colonization in fragmented nuthatch populations. Ecography. 23:614-622.

Verboom J, Shotman A, Opdam P, Metz JAJ. 1991. European nuthatch metapopulations in a fragmented agricultural landscape. Oikos. 61:149-156.

Verdú JR, Crespo MB, Galante E. 2000. Conservation strategy of a nature reserve in Mediterranean ecosystems: the effects of protection from grazing on biodiversity. Biodivers Conserv. 9:1707-1721.

Wrbka T, Schindler S, Pollheimer M, Schmitzberger I, Peterseil J. 2008. Impact of the Austrian AgriEnvironmental Scheme on diversity of landscape, plants and birds. Commun Ecol. 9:217-227.

Wrbka T, Szerencsits E, Moser D, Reiter K. 1999. Biodiversity patterns in cultivated landscapes: experiences and first results from a nationwide Austrian survey. In: Maudsley MJ, Marshall EJP editors. Heterogeneity in landscape ecology. Long Ashton, Bristol: IALE; pp. 3-17. 
Appendix A1. Order, family, phenology and frequency of occurrence (\%) during the breeding and non-breeding season of all bird species recorded in the 288 sampling points of the study area. According to their phenology, birds were classified as A: Reproductive in the area and leaving in the winter, M: migrant, R: Resident, and W: winter visitor.

\begin{tabular}{|c|c|c|c|c|c|}
\hline Order & Family & Scientific name & Phenology & $\begin{array}{l}\text { Breeding } \\
\text { season }\end{array}$ & $\begin{array}{l}\text { Non-breeding } \\
\text { season }\end{array}$ \\
\hline Caprimulgiformes & Caprimulgidae & $\begin{array}{c}\text { Caprimulgus } \\
\text { europaeus }\end{array}$ & $\mathrm{A} / \mathrm{M}$ & 0.68 & \\
\hline \multirow[t]{4}{*}{ Columbiformes } & \multirow[t]{4}{*}{ Columbidae } & Columba oenas & $\mathrm{A} / \mathrm{W}$ & & 0.34 \\
\hline & & Columba palumbus & $\mathrm{R}$ & & 1.03 \\
\hline & & Streptopelia decaocto & $\mathrm{R}$ & 4.11 & 2.05 \\
\hline & & Streptopelia turtur & $\mathrm{A} / \mathrm{M}$ & 8.56 & 0.34 \\
\hline \multirow[t]{2}{*}{ Coraciiformes } & Meropidae & Merops apiaster & $\mathrm{A} / \mathrm{M}$ & 6.85 & \\
\hline & Upupidae & Uрира ерорs & A & 9.25 & \\
\hline \multirow[t]{2}{*}{ Cuculiformes } & Cuculidae & Cuculus canorus & M & 4.79 & \\
\hline & Hirundinidae & Delichon urbica & M & 1.36 & \\
\hline Galliformes & Phasianidae & Coturnix coturnix & $\mathrm{A} / \mathrm{M}$ & 1.02 & \\
\hline \multirow[t]{36}{*}{ Passeriformes } & Aegithalidae & Aegithalos caudatus & $\mathrm{R}$ & 1.71 & 2.05 \\
\hline & \multirow[t]{3}{*}{ Alaudidae } & Alauda arvensis & $\mathrm{R}$ & 0.68 & 4.11 \\
\hline & & Galerida cristata & $\mathrm{R}$ & 13.35 & 13.01 \\
\hline & & Lullula arborea & $\mathrm{R}$ & 2.05 & \\
\hline & \multirow[t]{6}{*}{ Corvidae } & Corvus corax & $\mathrm{R}$ & & 5.14 \\
\hline & & Corvus corone cornix & $\mathrm{R}$ & 8.9 & 9.25 \\
\hline & & Corvus frugilegus & $\mathrm{R}$ & & 0.34 \\
\hline & & Corvus monedula & $\mathrm{R}$ & 0.34 & 1.03 \\
\hline & & Garrulus glandarius & $\mathrm{R}$ & 3.77 & 8.22 \\
\hline & & Pica pica & $\mathrm{R}$ & 12.33 & 17.46 \\
\hline & \multirow{4}{*}{ Emberizidae } & Emberiza cia & $\mathrm{R}$ & 0.34 & 0.34 \\
\hline & & Emberiza cirlus & $\mathrm{R}$ & 10.62 & 5.14 \\
\hline & & $\begin{array}{l}\text { Emberiza } \\
\quad \text { melanocephala }\end{array}$ & $\mathrm{A} / \mathrm{M}$ & 10.95 & \\
\hline & & Miliaria calandra & $\mathrm{R}$ & 18.83 & 3.42 \\
\hline & \multirow[t]{7}{*}{ Fringillidae } & Carduelis carduelis & $\mathrm{R}$ & 2.05 & 12.33 \\
\hline & & Carduelis chloris & $\mathrm{R}$ & 0.34 & 3.77 \\
\hline & & Carduelis spinus & $\mathrm{R}$ & & 3.08 \\
\hline & & $\begin{array}{l}\text { Coccothraustes } \\
\text { coccothraustes }\end{array}$ & $\mathrm{R}$ & & 0.34 \\
\hline & & Fringilla coelebs & $\mathrm{R}$ & 38.36 & 60.27 \\
\hline & & $\begin{array}{l}\text { Fringilla } \\
\quad \text { montifringilla }\end{array}$ & $\mathrm{W}$ & & 3.08 \\
\hline & & Serinus serinus & $\mathrm{R}$ & & 0.34 \\
\hline & Hirundinidae & Hirundo rustica & $\mathrm{A} / \mathrm{M}$ & 4.79 & \\
\hline & \multirow[t]{3}{*}{ Laniidae } & Lanius collurio & $\mathrm{A} / \mathrm{M}$ & 5.14 & \\
\hline & & Lanius minor & $\mathrm{A} / \mathrm{M}$ & 2.74 & \\
\hline & & Lanius senator & M & 2.39 & \\
\hline & \multirow[t]{2}{*}{ Motacillidae } & Anthus pratensis & W & & 0.34 \\
\hline & & Motacilla cinerea & $\mathrm{R}$ & 1.03 & 0.68 \\
\hline & \multirow[t]{6}{*}{ Muscicapidae } & $\begin{array}{l}\text { Luscinia } \\
\quad \text { megarhynchos }\end{array}$ & $\mathrm{A} / \mathrm{M}$ & 21.23 & \\
\hline & & Oenanthe hispanica & $\mathrm{A} / \mathrm{M}$ & 0.68 & \\
\hline & & Oenanthe oenanthe & $\mathrm{A} / \mathrm{M}$ & 0.68 & \\
\hline & & Phoenicurus ochruros & $\mathrm{R}$ & & 8.22 \\
\hline & & Saxicola rubetra & $\mathrm{A} / \mathrm{M}$ & 3.08 & \\
\hline & & Saxicola torquata & $\mathrm{R}$ & 0.68 & 3.42 \\
\hline & & Oriolus oriolus & $\mathrm{A} / \mathrm{M}$ & 5.14 & \\
\hline & \multirow{2}{*}{ Paridae } & Parus ater & $\mathrm{R}$ & & 0.68 \\
\hline & & Parus caeruleus & $\mathrm{R}$ & 8.21 & 6.85 \\
\hline
\end{tabular}


Appendix 1. (Continued).

\begin{tabular}{|c|c|c|c|c|c|}
\hline Order & Family & Scientific name & Phenology & $\begin{array}{l}\text { Breeding } \\
\text { season }\end{array}$ & $\begin{array}{l}\text { Non-breeding } \\
\text { season }\end{array}$ \\
\hline & & Parus lugubris & $\mathrm{R}$ & 2.05 & 1.03 \\
\hline & & Parus major & $\mathrm{R}$ & 14.72 & 26.37 \\
\hline & & Parus montanus & $\mathrm{R}$ & & 3.42 \\
\hline & & Parus palustris & $\mathrm{R}$ & 1.71 & 1.37 \\
\hline & \multirow[t]{3}{*}{ Ploceidae } & Passer domesticus & $\mathrm{R}$ & 18.49 & 11.3 \\
\hline & & Passer hispaniolensis & $\mathrm{A} / \mathrm{M}$ & 0.68 & \\
\hline & & Passer montanus & $\mathrm{R}$ & 0.34 & 0.68 \\
\hline & \multirow{2}{*}{ Regulidae } & Regulus ignicapilla & $\mathrm{R}$ & & 0.34 \\
\hline & & Regulus regulus & $\mathrm{R}$ & & 0.34 \\
\hline & Sittidae & Sitta europaea & $\mathrm{R}$ & 8.22 & 5.48 \\
\hline & Sturnidae & Sturnus vulgaris & $\mathrm{R}$ & 1.71 & 1.03 \\
\hline & \multirow[t]{7}{*}{ Sylviidae } & Hippolais pallida & $\mathrm{A} / \mathrm{M}$ & 10.96 & \\
\hline & & Phylloscopus collybita & $\mathrm{R}$ & 0.68 & 2.74 \\
\hline & & Sylvia atricapilla & $\mathrm{R}$ & 0.34 & 1.37 \\
\hline & & Sylvia cantillans & $\mathrm{A} / \mathrm{M}$ & 14.72 & \\
\hline & & Sylvia communis & $\mathrm{A} / \mathrm{M}$ & 5.14 & \\
\hline & & Sylvia hortensis & $\mathrm{A} / \mathrm{M}$ & 2.39 & \\
\hline & & Sylvia melanocephala & $\mathrm{R}$ & 0.34 & \\
\hline & Troglodytidae & $\begin{array}{l}\text { Troglodytes } \\
\quad \text { troglodytes }\end{array}$ & $\mathrm{R}$ & & 9.25 \\
\hline & \multirow{5}{*}{ Turdidae } & Erithacus rubecula & $\mathrm{R}$ & 1.37 & 48.97 \\
\hline & & Turdus iliacus & $\mathrm{R}$ & & 0.34 \\
\hline & & Turdus merula & $\mathrm{R}$ & 11.98 & 35.27 \\
\hline & & Turdus philomelos & $\mathrm{R}$ & & 5.48 \\
\hline & & Turdus viscivorus & $\mathrm{R}$ & & 0.34 \\
\hline \multirow[t]{3}{*}{ Piciformes } & \multirow[t]{3}{*}{ Picidae } & Dendrocopos major & $\mathrm{R}$ & & 5.14 \\
\hline & & Dendrocopos medius & $\mathrm{R}$ & 0.68 & 0.34 \\
\hline & & Dendrocopos syriacus & $\mathrm{R}$ & 3.77 & 0.68 \\
\hline Strigiformes & Strigidae & Athene noctua & $\mathrm{R}$ & 1.03 & 1.03 \\
\hline
\end{tabular}

